\title{
KOPALNIA DOŚWIADCZALNA „BARBARA”, CENTRALA RATOWNICTWA GÓRNICZEGO I OBSERWATORIUM MAGNETYCZNE W MIKOLOWIE
}

\author{
Stefan GIERLOTKA
}

Stowarzyszenie Inżynierów i Techników Górnictwa, gierlotkastefan@interia.pl

\author{
historia górnictwa, \\ zagrożenie wybuchowe w kopalniach, \\ ratownictwo górnicze
}

Po plebiscycie i podziale Górnego Śląska w 1922 roku Górnośląska Centralna Stacja Ratownictwa Górniczego w Bytomiu pozostała na terytorium Niemiec. W 1925 roku zorganizowano stację ratownictwa górniczego w polskiej części Górnego Śląska, w okolicach Tarnowskich Gór. W 1926 roku, z powodów lokalnych uciążliwości, stację przeniesiono do Mikołowa, gdzie przyjęła ona nazwę Kopalnia Doświadczalna „Barbara”, Centrala Ratownictwa Górniczego i Obserwatorium Magnetyczne. W stacji prowadzono prace naukowo-badawcze z zakresu zagrożeń gazowych i pożarowych oraz związanych z wybuchami pyłu węglowego. Osobnym działem kopalni było Obserwatorium Magnetyczne prowadzące badania nad zmianami deklinacji magnetycznej, potrzebnej dla wykonywania orientacji wyrobisk górniczych.

Po drugiej wojnie światowej Centralną Stację Ratownictwa Górniczego przeniesiono do Bytomia. Kopalnia doświadczalna Barbara została włączona do Głównego Instytutu Górnictwa w Katowicach. Kontynuowano w niej nadal prace naukowe w zakresie zwalczania zagrożeń wybuchów metanu, pyłu węglowego oraz stosowania materiałów wybuchowych w kopalniach. Rozwój elektryfikacji kopalń metanowych, jaki odbywał się po wojnie, wymusił rozbudowę jednostki o dział badań i atestacji urządzeń elektrycznych budowy przeciwwybuchowej.

\section{Kopalnia Anna w Mikołowie przekształcona w kopalnię Barbara}

W połowie dziewiętnastego stulecia nastąpił znaczny wzrost popytu na węgiel $\mathrm{w}$ rozwijającym się przemyśle. W wyniku rosnącego zapotrzebowania, 
w 1850 roku książę pszczyński Jan Henryk X Hochberg uruchomił w Mikołowie kopalnię „Anna”, usytuowaną na wzgórzu Kamionka. Kopalnia miała wydobywać węgiel koksujący i zaopatrywać butę żelaza „Ida” (Idahütte) w Ligocie, dzisiejszej dzielnicy Katowic. W kopalni „Anna” rozpoczęto eksploatację w płytko zalegającej wychodni pokładu węgla koksującego początkowo o grubości około 1,6 m. Wydobycie w 1852 roku wynosiło 2906 ton, przy przeciętnym zatrudnieniu 34 górników (Dubiński, 2005). W latach następnych nastąpiło zmniejszenie miąższości tego pokładu i wstrzymano wydobycie. Ponieważ węgiel z sąsiednich pokładów nie miał właściwości przydatnych do hutniczego procesu wielkopiecowego, kopalnia zaprzestała wydobycia. W kolejnych latach kopalnię Anna otwierano i zamykano wielokrotnie.

W 1920 roku Dyrekcja Kopalń Księcia Pszczyńskiego (Fürstlich Plessische Bergwerk-Direktion), w rejonie dawnej kopalni „Anna”, otwarła nową kopalnię w Zarzeczu koło Mikołowa. W 1921 roku Wyższy Urząd Górniczy we Wrocławiu wyraził zgodę na nadanie kopalni nazwę Barbara (ryc. 1). Wydobycie początkowo było niewielkie, sięgające około 15 tys. ton rocznie (Zielińska, 2015). $\mathrm{Z}$ powodu braku bocznicy kolejowej, wydobyty węgiel wywożono z kopalni samochodami i furmankami. Później rozpoczęto głębienie szybu wydobywczego w dzielnicy Mikołowa Gniotek oraz budowę zakładu separacji węgla, a także bocznicy kolejowej do istniejące trakcji relacji Katowice - Tychy. W tym celu wycięto dużą połać lasu pod trasę torowiska i wybudowano dwa wiadukty kolejowe (ryc. 2).

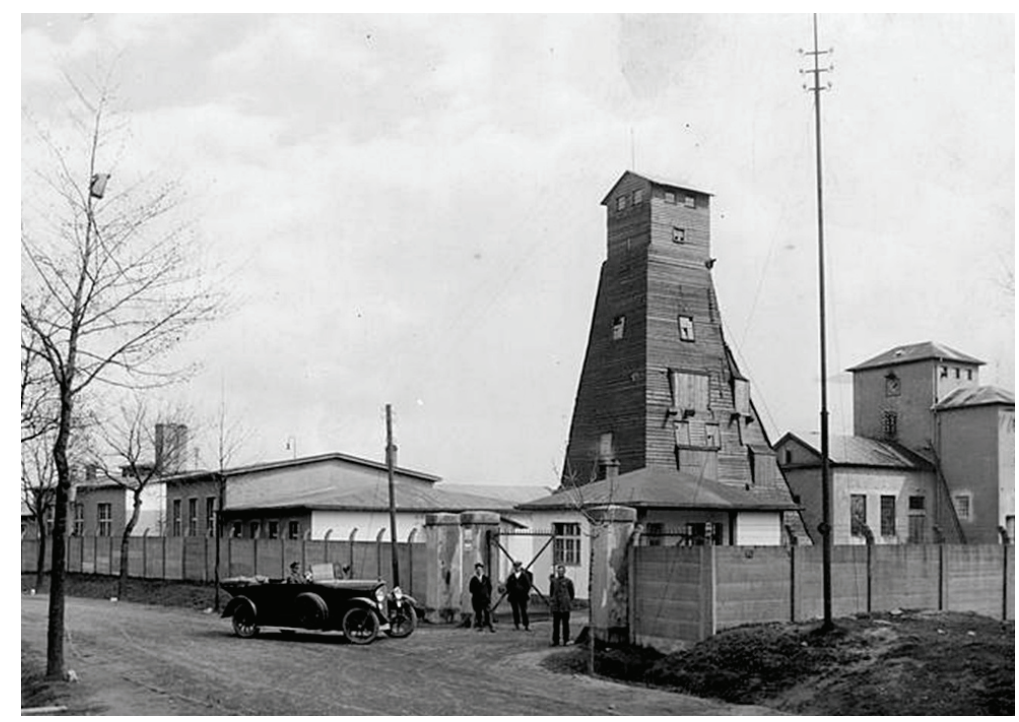

Ryc. 1. Widok kopalni „Barbara” w latach 20-tych XX wieku (ze zbioru autora)

Fig. 1. The view of "Barbara" Mine in the 1920s of XX century (from the author's collection) 
Z nastaniem kryzysu gospodarczego w górnictwie i problemami ze zbytem węgla, dalszą budowę kopalni wstrzymano. Ogólny zastój w górnictwie śląskim spowodował, że od sierpnia 1924 roku kopalnia była nieczynna. Przygotowaną trasę pod trakcję kolejową porósł las, a w nim stoją do dzisiaj dwa betonowe wiadukty kolejowe (ryc. 2).

$\mathrm{W}$ okresie kryzysu, $\mathrm{z}$ końcem lat dwudziestych i w latach trzydziestych $\mathrm{XX}$ wieku, na obszarze górniczym Gniotek rozwinęło się nielegalne górnictwo węgla w biedaszybach, co związane było z bezrobociem górników i kryzysem gospodarczym okresu międzywojennego.

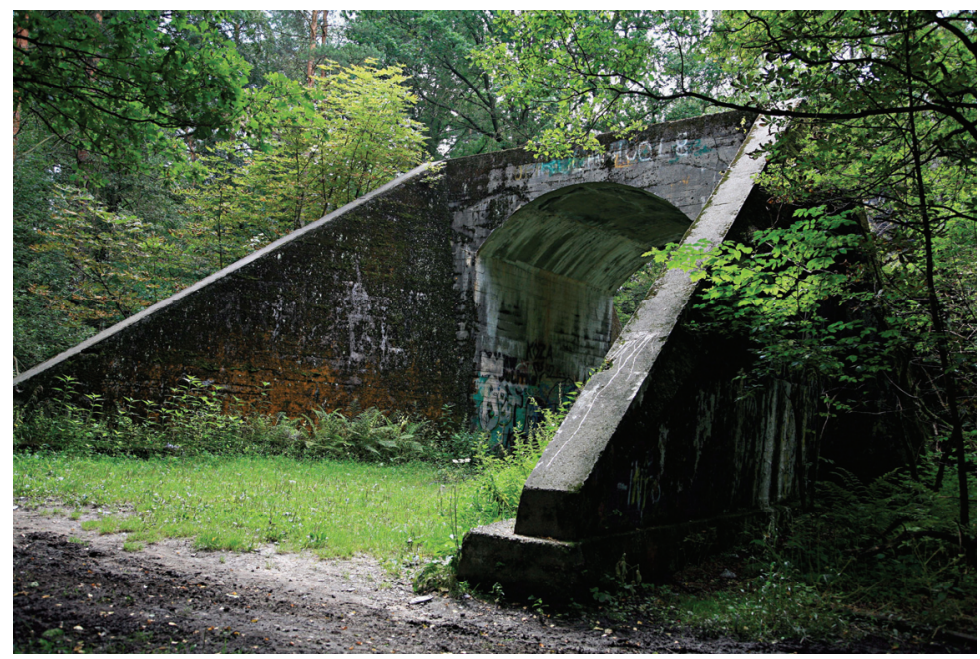

Ryc. 2. Pozostawiony w lesie wiadukt kolejowy po niedokończonej bocznicy kolejowej

Fig. 2. The railway viaduct used to build unfinished sidetrack left in the forest

\section{Stacja ratownictwa górniczego w Bytomiu}

Pierwsza Stacja Ratownictwa Górniczego na Górnym Śląsku została utworzona w 1907 roku, w Bytomiu. Jej dyrektorem był Bergassessor Hans Woltersdorf (Gierlotka, 2017).

W wyniku przeprowadzonego plebiscytu na Górnym Śląsku, decyzją Rady Ambasadorów z 20 października 1921 roku, na podstawie 1 art. 88 Traktatu Wersalskiego, nastąpił podział Śląska między Niemcy i Polskę. Zmiana granicy państwowej pociągnęła za sobą konieczność zmian organizacyjnych w górniczej części Górnośląskiego Zagłębia Węglowego. Biorąc pod uwagę fakt, że po podziale Śląska Bytom, a wraz z nim działająca Centralna Stacja Ratownictwa, znalazły się po stronie niemieckiej, konieczne stało się utworzenie stacji ratow- 
nictwa górniczego dla kopalń polskich. Z inicjatywy Stanisława Majewskiego, wicedyrektora Wyższego Urzędu Górniczego, przystąpiono do tworzenia polskiej stacji naukowo-badawczej dla zapewnienia bezpieczeństwa pracy w kopalniach. W 1925 roku utworzono Stację Doświadczalną i Centralę Ratownictwa Górniczego na terenie Fabryki Materiałów Wybuchowych „Lignoza” w Pniowcu koło Tarnowskich Gór. Dyrektorem stacji został inż. Józef Juroff. Zadaniem tego ośrodka było prowadzenie badań nad zagrożeniami górniczymi i przyczynami katastrof górniczych. Stacja finansowana była przez Górnośląski Związek Kopalń i Hut jako jednostka badawcza dla rozwiązywania problemów bezpieczeństwa w kopalniach (Dubiński, 2005). Stacja dysponowała dwudziestometrową sztolnią, w której prowadzono badania nad wybuchowością pyłu węglowego i gazów w kopalniach. Wylot sztolni doświadczalnej był blisko niemieckiej granicy $(500 \mathrm{~m})$ i znajdował się w pobliżu zabudowań wioski Boruszowice. $Z$ racji tego, że eksperymentalne wybuchy często przeprowadzano nocą, zaczęło doprowadzać to do konfliktów z mieszkańcami wsi. Zła lokalizacja i uciążliwości powodowane nocnymi wybuchami przyczyniły się do przeniesienia stacji po roku do wynajętej nieczynnej kopalni „Barbara” w Mikołowie.

\section{Kopalnia doświadczalna „Barbara” w Mikołowie}

W 1926 roku nieczynną kopalnię „Barbara” w Mikołowie (dawniej kopalnia „Anna”) wydzierżawił od księcia pszczyńskiego za 2200 franków szwajcarskich Górnośląski Związek Kopalń i Hut. Do niej w 1926 roku została przeniesiona Stacja Doświadczalna i Centrala Ratownictwa Górniczego. Utworzony nowy ośrodek w Mikołowie otrzymał nazwę „Kopalnia Doświadczalna Barbara, Centrala Ratownictwa Górniczego i Obserwatorium Magnetyczne w Mikołowie" (Gierlotka, 2017).

Dzierżawa obejmowała budynki zabudowy kopalni, szyb z wyposażeniem maszynowym oraz wyrobiska górnicze na poziomie $46 \mathrm{~m}$. Zawarta umowa określała używanie dzierżawy tylko do celów związanych z działalnością doświadczalną ośrodka i potrzebami stacji ratownictwa. Zabronione było wydobywanie węgla i wykonywanie robót eksploatacyjnych.

Po przejęciu kopalni przystąpiono do wykonywania poligonu doświadczalnego. Na poziomie $46 \mathrm{~m}$ wykonano chodnik doświadczalny długości $120 \mathrm{~m}$, a na powierzchni sztolnię o długości $40 \mathrm{~m}$. W następnych latach wybudowano młyny węglowe, rozbudowano warsztat elektryczny i mechaniczny oraz nowe laboratoria. Liczba zatrudnionych w 1928 roku wynosiła 30 osób (Dubiński, 2005). 
Zadaniem kopalni było prowadzenie badań nad wybuchowością pyłów i gazów kopalnianych oraz bezpiecznym stosowaniem materiałów wybuchowych. Kopalnia Doświadczalna „Barbara” była pierwszą w Polsce jednostką prowadzącą badania na rzecz bezpieczeństwa pracy w górnictwie. Na jej terenie znajdowała się też Centrala Ratownictwa Górniczego, która zajmowała się zagadnieniami związanymi $\mathrm{z}$ organizacją ratownictwa górniczego. W kopalni prowadzono szkolenia podstawowe i okresowe dla ratowników górniczych ze wszystkich polskich kopalń (ryc. 3).

Kopalnia Doświadczalna „Barbara” od powstania w 1926 roku była finansowana przez Związek Przemysłowców Górniczo-Hutniczych. Przedsiębiorstwa górnicze całego Górnośląskiego Zagłębia Węglowego płaciły składki na utrzymanie tego ośrodka. Po 1933 roku była finansowana z funduszy Stowarzyszenia Kopalni Doświadczalnej Barbara. Kopalnia podlegała bezpośrednio Wyższemu Urzędowi Górniczemu (Dubiński, 2005).

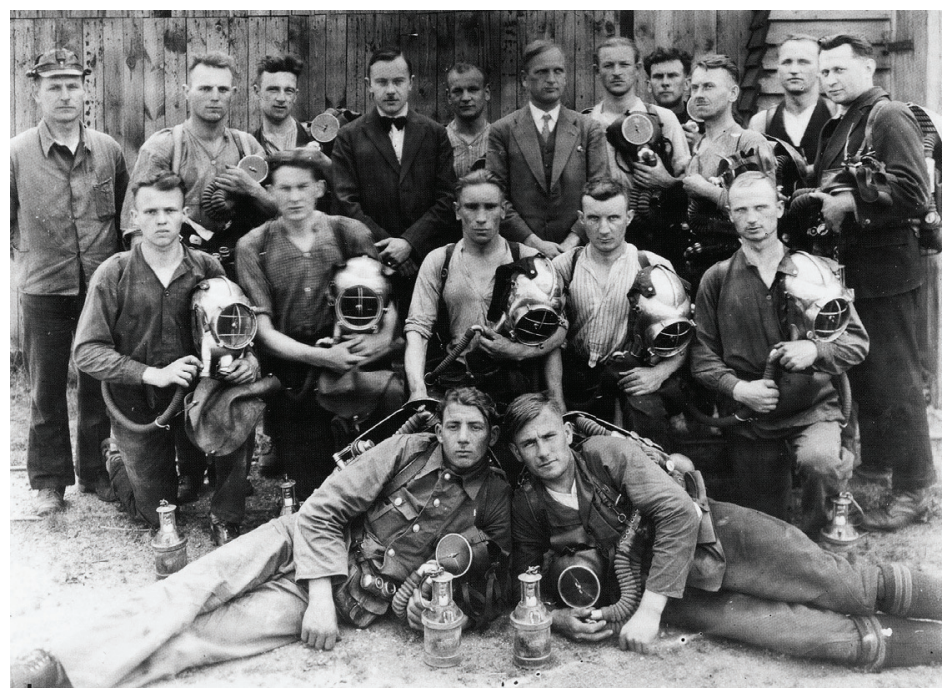

Ryc. 3. Uczestnicy kursu ratownictwa górniczego w latach dwudziestych XX wieku (ze zbioru autora)

Fig. 3. Participants of mining rescue course in 1920s of XX centrury (from the author's collection)

Dyrektorami Kopalni Doświadczalnej Barbara w okresie międzywojennym byli: Józef Juroff w latach 1925-1930 i Stanisław Herman w latach 1930-1939. Zastępcą dyrektora od 1928 roku był Wacław Cybulski (Dubiński, 2005).

Już $\mathrm{w}$ pod koniec lat 20. ubiegłego wieku podjęto $\mathrm{w}$ ośrodku prace naukowe w zakresie zwalczania zagrożeń wybuchów metanu i pyłu węglowego w kopalniach. Badania prowadzono pod względem inicjacji wybuchu metanu od robót 
górniczych z użyciem materiałów wybuchowych oraz od urządzeń elektrycznych. Przeprowadzono ocenę wszystkich urządzeń elektrycznych stosowanych w wyrobiskach kopalń gazowych, które mogły stanowić przyczynę zapłonu pyłu węglowego i metanu. Wyniki tych badań stanowiły podstawy dla tworzenia przepisów.

Od początku lat 30. ubiegłego wieku były prowadzone badania wybuchów w sztolniach doświadczalnych oraz badania nad zaporami z pyłu kamiennego do tłumienia wybuchów pyłu węglowego. Badania były prowadzone pod kierunkiem Wacława Cybulskiego. W tym czasie zostały opracowane pierwsze metody opylania wyrobisk górniczych oraz pyłowe zapory przeciwwybuchowe dla thumienia wybuchów pyłu węglowego. Opracowano nowe materiały wybuchowe bezpieczne wobec metanu i pyłu.

W Kopalni Doświadczalnej Barbara, w okresie poprzedzającym wybuch drugiej wojny, opracowano wiele rozwiązań w zakresie budowy przeciwwybuchowej urządzeń elektrycznych, przeznaczonych do pracy w kopalniach gazowych. Pracowano nad zasadami dopuszczania urządzeń i sprzętu elektrycznego do stosowania w warunkach zagrożenia gazowego kopalń.

Krótko przed wybuchem drugiej wojny światowej najważniejsze aparaty do rejestracji, i chronografy przewieziono do Białej Podlaskiej oraz na Uniwersytet Jagielloński. Dyrektor kopalni Stanisław Herman i Wacław Cybulski opuścili Polskę jeszcze przed wkroczeniem wojsk niemieckich (Zielińska, 2015). Po wkroczeniu wojsk niemieckich, w 1939 roku, kopalnia była nieczynna. Jednakże po roku znów wznowiono, początkowo sporadyczne, badania w sztolni doświadczalnej. W okresie okupacji kopalnia Barbara należała do Oberschlesische Hauptstelle für das Grubenrettungswesen und Versuchsstrecke i podlegała pod tzw. Knappschaft. Kopalnią w tym okresie zarządzał Ernst Ebbinghaus - absolwent Bergbauakademie w Berlinie. Zatrudnieni tam pracownicy, w okresie wojny, gdy nie prowadzono badań, zajmowali się produkcją noszy górniczych i pompowaniem wody, by nie dopuścić do zatopienia wyrobisk.

\section{Kopalnia doświadczalna Barbara w okresie powojennym}

W 1945 roku powstał Instytut Naukowo-Badawczy Przemysłu Węglowego w Katowicach, przemianowany w 1950 roku na Główny Instytut Górnictwa. Kopalnia Doświadczalna „Barbara” w Mikołowie, licząca wówczas 40 pracowników, została do niego włączona jako odrębny zakład. Jej dyrektorem w 1945 roku został przedwojenny dyrektor Stanisław Herman, a rok później - Wacław Cybulski (ryc. 4). W 1947 roku Centralną Stację Ratownictwa Górniczego przeniesiono z Mikołowa do Bytomia, tworząc samodzielną jednostkę. 
W latach powojennych wybudowano nową sztolnię doświadczalną. Stanowiła ją rura stalowa o długości $100 \mathrm{~m}$ i średnicy $2 \mathrm{~m}$, zamknięta w jednym końcu i otwarta w przeciwnym. Kopalnia Doświadczalna Barbara była jedyną placówką naukowo-badawczą w Europie, dysponującą podziemnym poligonem doświadczalnym.

Zakres prowadzonych badań obejmował: zwalczanie zagrożenia pyłowego i gazowego, badanie i dopuszczanie do stosowania urządzeń elektrycznych przeciwwybuchowych.

W 1969 roku placówka otrzymała nazwę: Instytut Bezpieczeństwa Górniczego - Kopalnia Doświadczalna „Barbara”, a zakres jej badań został rozszerzony o badanie wyrzutów gazów i skał, prognozę metanowości, odmetanowanie, manometrię indywidualną i stacjonarną.

Prowadzone w kopalni badania wybuchów pyłu węglowego były wykonywane w podziemnych chodnikach doświadczalnych o łącznej długości $920 \mathrm{~m}$, w tym $740 \mathrm{~m} \mathrm{w}$ jednym ciągu (Dubiński, 2005). Chodniki zostały wyposażone w systemy pomiaru podstawowych parametrów przebiegu wybuchu: prędkości i zasięgu płomienia, ciśnienia statycznego i dynamicznego. Wyniki tych badań dawały merytoryczne podstawy do tworzenia przepisów.

Ryc. 4. Prof. Wacław Cybulski (ze zbioru autora)

Fig. 4. Prof. Wacław Cybulski (from the author's collection)

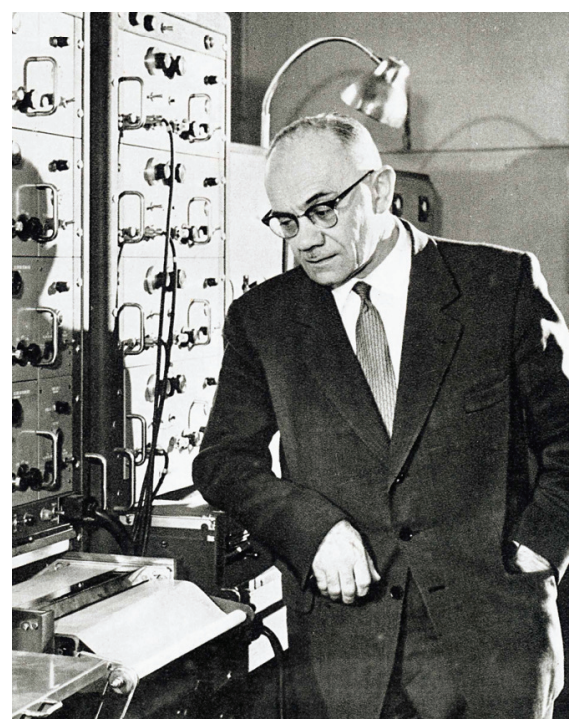

Po śmierci Wacława Cybulskiego w 1973 roku, dyrektorem kopalni i ośrodka badawczego został Jerzy Matuszewski. Od 1981 do 2003 dyrektorem był Paweł Krzystolik, a następnie Krzysztof Cybulski (Dubiński, 2005).

Wraz z wprowadzeniem energii elektrycznej do podziemnych wyrobisk górniczych, zwłaszcza w kopalniach metanowych, powstał problem elektrycznych urządzeń przeciwwybuchowych. Problematykę tę podjęła Kopalnia Doświad- 
czalna Barbara już w 1945 roku, organizując Zakład Bezpieczeństwa Urządzeń Elektrycznych, który następnie przekształcił się w Zakład Elektrycznych Urządzeń Przeciwwybuchowych. Prace prowadzone w tym dziale stworzyły podstawę do opracowania norm określających wymagania konstrukcyjne i technologiczne, jakim powinny odpowiadać urządzenia elektryczne przeznaczone do stosowania w kopalniach metanowych (Gierlotka, 2017). Uzyskały one rangę norm państwowych. $\mathrm{Na}$ nich opierają się badania atestacyjne urząazzeń elektrycznych przeciwwybuchowych, których wyniki stanowią podstawę dla decyzji Wyższego Urzędu Górniczego o dopuszczeniu do stosowania w kopalniach metanowych.

\section{Górnicze Obserwatorium Magnetyczne w Mikołowie}

W 1926 roku, po przeniesieniu z Tarnowskich Gór Stacji Doświadczalnej i Centrali Ratownictwa Górniczego do kopalni doświadczalnej Barbara w Mikołowie, powstała Centrala Ratownictwa Górniczego i Obserwatorium Magnetyczne w Mikołowie.

Obserwatorium magnetyczne, zwane także stacją magnetyczną, należące do Kopalni Doświadczalnej Barbara, znajdowało się na terenie Mikołowa, ale było oddalone od kopalni o 3,5 km w kierunku Łazisk Górnych. Sam budynek obserwatorium, wzniesiony z cegły - umiejscowiony był w terenie niezabudowanym, na zboczu wzniesienia, po prawej stronie dzisiejszej ul. Rybickiego. Miejsce na którym wybudowano Obserwatorium Magnetyczne, należało wówczas do mikołowskiego Bractwa Strzeleckiego. Obok budynku obserwatorium umiejscowiona była głęboka cysterna, w której umieszczano sprzęt do pomiarów zmian deklinacji magnetycznej.

Konstanty Prus w swojej książce wydanej w 1932 roku (Prus, 1932) opisuje ten ośrodek badawczy. „Obserwatorium magnetyczne istnieje w Mikołowie obok kolonii zwanej Wymyślanką i służy również do celów górniczych. Zbudowała je Górnośląska Pomocnicza Kasa Górnicza. Pierwotnie obserwatorium to istniało w Bytomiu, ale ponieważ tam miejsce nie było odpowiednie i właściwe, zbudowano kosztem 25000 marek nową stację w Mikołowie, dokąd w roku 1912 całe obserwatorium z Bytomia przeniesiono i wzorowo urządzono. Obserwatorium to posiada samoczynne dokładne aparaty, które zapisują wszelkie odchylenia czyli deklinacje prądu magnetycznego od linii magnetycznej $\mathrm{N}-\mathrm{S}$. Wskazania tych aparatów odpisuje się regularnie co dzień; wykazy te potem udostępnia się kopalniom oraz ogłasza raz w miesiącu w czasopiśmie Górnośląskich Przemysłowców Górniczo-Hutniczych. A są one bardzo ważne 
do wytyczania ganków podziemnych i do rysowania dokładnych map podziemi kopalnianych. Górnik bowiem w kopalni kieruje się kompasem przy wytyczaniu kierunku dróg i chodników, a kompas kieruje się według prądu magnetycznego ziemi; prąd ten jednak często odchyla się mniej lub więcej od prostej linii $\mathrm{N}-\mathrm{S}$; miernicy kopalniani muszą znać te odchylenia, kiedy one były i jak wielkie, i wziąć je dokładnie w rachubę przy pomiarach podziemnych, wytyczaniu kierunków i dróg pod ziemią i przy sporządzaniu map labiryntów podziemnych".

Wartość deklinacji magnetycznej w danym miejscu zmienia się w czasie. Roczne zmiany deklinacji wynoszą od $5^{\prime}$ do $15^{\prime}$. Nieregularne zmiany deklinacji, spowodowane burzami magnetycznymi, mogą dochodzić do kilku stopni (Kowalczyk, 1968). Przyczyny te powodują konieczność sprawdzania deklinacji $\mathrm{w}$ czasie prowadzenia pomiarów przy pomocy przyrządów z igłą magnetyczną. Na podstawie zmian pomiarów ziemskiego pola magnetycznego sporządzano mapy magnetyczne, na których nanoszone były linie jednakowej deklinacji, czyli tzw. izogony.

Pierwsze na obszarze Polski obserwatorium magnetyczne dla geodezji naziemnej założył w 1910 r. Stanisław Kalinowski w Świdrze pod Warszawą (Kowalczyk, 1968). Obecnie ciągłą rejestrację składowych pola geomagnetycznego na terenie kraju prowadzą: Obserwatorium Geofizyczne Polskiej Akademii Nauk na Półwyspie Helskim oraz Centralne Obserwatorium Geofizyczne Polskiej Akademii Nauk w Belsku Dużym (woj. Radomskie). Poza tym rejestrację magnetyczną o charakterze uzupełniającym prowadzi Śląskie Obserwatorium Geofizyczne PAN w Raciborzu.

Dane z obserwatorium magnetycznego wykorzystywane były w kopalniach przy wykonywaniu orientacji wyrobisk. Mierniczego górniczego interesowały aktualne wariacje deklinacji, które regularnie podawała stacja magnetyczna (Gierlotka, 2012). Orientację wyrobisk prowadzono z użyciem kompasu górniczego. Mapy górnicze orientowane były do współrzędnych geograficznych. Różnicę deklinacji magnetycznej do geograficznego układu odniesienia podawała stacja Obserwatorium Magnetyczne w Mikołowie.

$\mathrm{Z}$ czasem stosowanie metody orientacji wyrobisk przy pomocy kompasu górniczego straciło na znaczeniu, głównie za sprawą zakłócającego oddziaływania urządzeń mechanicznych i stosowania stalowej obudowy wyrobisk. Stąd też, w latach powojennych, zapadła decyzja o likwidacji tego obiektu.

Był on widocznym z daleka budynkiem z czerwonej cegły, jednak jego konstrukcja musiała być na tyle mocna, że do rozbiórki użyto materiału wybuchowego. Jego gruzy całkowicie zniknęły dopiero podczas budowie nowego osiedla domów o zabudowie szeregowej przy ul. Konstytucji 3 Maja 75. Do dziś na Filipowcj Górce, jak czasem miejscowi nazywają to wzniesienie, ocalał jedynie fragment oryginalnego, betonowego muru, który ją niegdyś otaczał. 


\title{
Literatura
}

DUBIŃSKI J., 2005. Historia i teraźniejszość 60-lecia Głównego Instytutu Górnictwa, 80-lecia Kopalni Doświadczalnej Barbara. GIG Katowice.

GIERLOTKA S., 2012. Rozwój techniki miernictwa górniczego. Bezpieczeństwo Pracy i Ochrona Środowiska w Górnictwie. Bezp. Pracy i Ochr. Środ. w Górnictwie. Miesięcznik WUG, 211, 3: 51-52.

GIERLOTKA S., 2017. Historia górnictwa - technika/mechanizacjalelektryfikacja. Wydanie II. Wydawnictwo Naukowe Śląsk - Katowice.

GIERLOTKA S., 2017. Rozwój elektrycznych urządzeń budowy przeciwwybuchowej dla kopalń metanowych. Hered. Min., 4: 191-199.

KOWALCZYK Z., 1968. Pomiary sytuacyjno-wysokościowe kopalń. Wyd. Śląsk. Katowice.

PRUS K., 1932. Z dziejów Mikołowa i jego okolicy. Mikołów.

ZIELIŃSKA M., 2015. 90 lat pracy dla górnictwa 1925-2015. Wyd. GIG. Katowice.

\section{THE EXPERIMENTAL MINE "BARBARA", UPPERSILESIAN CENTRAL MINING RESCUE STATION AND MAGNETIC OBSERVATORY IN MIKOŁÓW}

\author{
mining history, \\ explosive threat in mines, \\ mining rescue
}

Upper Silesian Central Mining Rescue Station in Bytom was left on German territory after the division of Upper Silesia in 1922. A new station was founded in Tarnowskie Gory (Polish part of Upper Silesia) in 1925. Due to regional problems the station was moved to Mikołów a year later. The new station was named the Experimental Mine Barbara, Upper Silesian Central Mining Rescue Station and Magnetic Observatory. Scientific and research studies exploring the dangers of coal dust or gas explosions and fire protection were conducted in this station. Another section of the coal mine was the Magnetic Observatory that did research on magnetic changes used for orientation during mining excavations.

After the Second World War the station was moved to Bytom. The experimental Mine „Barbara" was included into the Main Mining Institute in Katowice. The scientific studies on the dangers of methane or coal dust explosions and research concerning explosive materials in coal mines were continued. The development of electrification in coal mines that took place after the War led to the development of the department of research, certification and inspection of electric devices. 